\title{
Formation, microstructure and properties of aluminum borate ceramics obtained from alumina and boric acid
}

\author{
María F. Hernández ${ }^{\mathrm{a}, \mathrm{b}, *}$, Gustavo Suárez ${ }^{\mathrm{a}, \mathrm{b}}$, Mariano Cipollone ${ }^{\mathrm{b}, \mathrm{c}}$, María S. Conconi $^{\mathrm{a}}$, \\ Esteban F. Aglietti ${ }^{\mathrm{a}, \mathrm{b}}$, Nicolás M. Rendtorff ${ }^{\mathrm{a}, \mathrm{b}}$ \\ a Centro de Tecnología de Recursos Minerales y Cerámica CETMIC (CIC-CONICET) Cno., Centenario y 506 Gonnet, La Plata 1897, Argentina \\ b Departamento de Química, Facultad de Ciencias Exactas UNLP, 47 y 115, La Plata 1900, Argentina \\ c Química Analítica, Y-TEC SA, Ensenada, Argentina
}

\section{A R T I C L E I N F O}

\section{Keywords:}

Porous ceramics

Aluminum borate

Processing

Characterization

\begin{abstract}
A B S T R A C T
The formation of aluminum borates $\left(\mathrm{Al}_{18} \mathrm{~B}_{4} \mathrm{O}_{33}\right.$ and $\left.\mathrm{Al}_{4} \mathrm{~B}_{2} \mathrm{O}_{9}\right)$ from alumina and boron oxide occurs between 600 and $800{ }^{\circ} \mathrm{C}$. These materials have refractory properties and corrosion resistance. The objective of this work is to develop materials from the $\mathrm{Al}_{2} \mathrm{O}_{3}-\mathrm{B}_{2} \mathrm{O}_{3}$ system, employing alumina and boric acid as starting powders, to study the critical processing variables and describe the developed microstructure and properties.

Three formulations $\left(13,19.5\right.$ and $26 \mathrm{wt} \% \mathrm{~B}_{2} \mathrm{O}_{3}$ ) were studied. In order to confirm the formation of borates, the differential thermal analysis and thermogravimetric analysis were carried out. Afterwards, uniaxially pressed disc-shaped specimens were fired at four temperatures above the formation temperature. The textural properties of the ceramics were evaluated by the immersion method, this permit to evaluate the sintering processes. Then the degree of borate formation was confirmed by X-ray diffraction.

Finally, the developed microstructures were characterized by scanning electron microscopy, and the diametral compression behavior was evaluated.

A series of porous $(\approx 50 \%)$ refractory materials from the $\mathrm{Al}_{2} \mathrm{O}_{3}-\mathrm{B}_{2} \mathrm{O}_{3}$ system were developed. The processing strategy resulted in materials with $\mathrm{Al}_{18} \mathrm{~B}_{4} \mathrm{O}_{33}$ as the main crystalline phase. Needle grains with diameters between 0.2 and $1 \mu \mathrm{m}$ and an aspect ratio over 20:1 were obtained. Thus, based on the information gathered from our research, aluminum borate ceramic materials can be designed for structural, insulating or filtering applications employing only alumina and boric acid as boron oxide source.
\end{abstract}

\section{Introduction}

The $\mathrm{Al}_{2} \mathrm{O}_{3}-\mathrm{B}_{2} \mathrm{O}_{3}$ phase diagram (Fig. 1) was fully described fifty years ago [1]. Two aluminum borates are stable in the binary system $\mathrm{Al}_{18} \mathrm{~B}_{4} \mathrm{O}_{33}$ and $\mathrm{Al}_{4} \mathrm{~B}_{2} \mathrm{O}_{9}$. While the first is stable up to $1900{ }^{\circ} \mathrm{C}$ and the second one is stable only up to $1100^{\circ} \mathrm{C}$. The formation of boron aluminates (BA) and $\mathrm{Al}_{18} \mathrm{~B}_{4} \mathrm{O}_{33} \mathrm{Al}_{4} \mathrm{~B}_{2} \mathrm{O}_{9}$ from alumina and boron oxide occurs between 600 and $800{ }^{\circ} \mathrm{C}$. In the high $\mathrm{B}_{2} \mathrm{O}_{3}$ content region $\left(\mathrm{B}_{2} \mathrm{O}_{3}\right.$ $>25 \mathrm{wt} \%)$ the first liquid phase will appear at temperatures around $450{ }^{\circ} \mathrm{C}$, which corresponds to the pure oxide melting point.

Materials based in these phases present high refractoriness as well as chemical inertness in some environments [2]; the catalytic properties of these phases for some technological reactions are also remarkable [3-5]. Aluminum borate thermal conductivity is between 6 and $4 \mathrm{~W} \mathrm{~m}^{-1} \mathrm{~K}^{-1}$ in the room temperature $1000{ }^{\circ} \mathrm{C}$ range. These present a Young modulus of $\approx 400 \mathrm{GPa}$, a tensile strength of $\approx 8 \mathrm{GPa}$, and a Mohs hardness of 7 . Finally the thermal expansion coefficients are $\approx 4.5$ and $\approx 1.9\left(\times 10^{-6}{ }^{\circ} \mathrm{C}^{-1}\right)$ in the axial and radial directions respectively [6].

The utilization of aluminum borate needles or whiskers for aluminum and aluminum based alloy reinforcement is the main application of these phases [6]. They have also been proposed for the reinforcement of magnesium alloys [7]. The mechanical behavior of the material, the chemical compatibility (low wettability) of borate with metallic aluminum, and the microstructural configuration of the metalceramic composites encourage these particular applications. The mechanical behavior of the composites is better than that of the corresponding metallic materials. Vitroceramics with aluminum borates as crystalline phase were also studied, showing technological properties [8]. Furthermore, aluminum borates have also been used as refractory, insulating or filtering materials [4-8].

In addition to the reaction sintering from alumina and boric oxide [9-11], some synthetic routes have been proposed and studied, including the flux method [12], crystallization from molten salts [13], sol-gel routes and chemical precursors [14-17], and the combustion

\footnotetext{
* Corresponding author at: Centro de Tecnología de Recursos Minerales y Cerámica CETMIC (CIC-CONICET) Cno., Centenario y 506 Gonnet, La Plata 1897, Argentina.

E-mail address: florenciahernandez@cetmic.unlp.edu.ar (M.F. Hernández).
} 


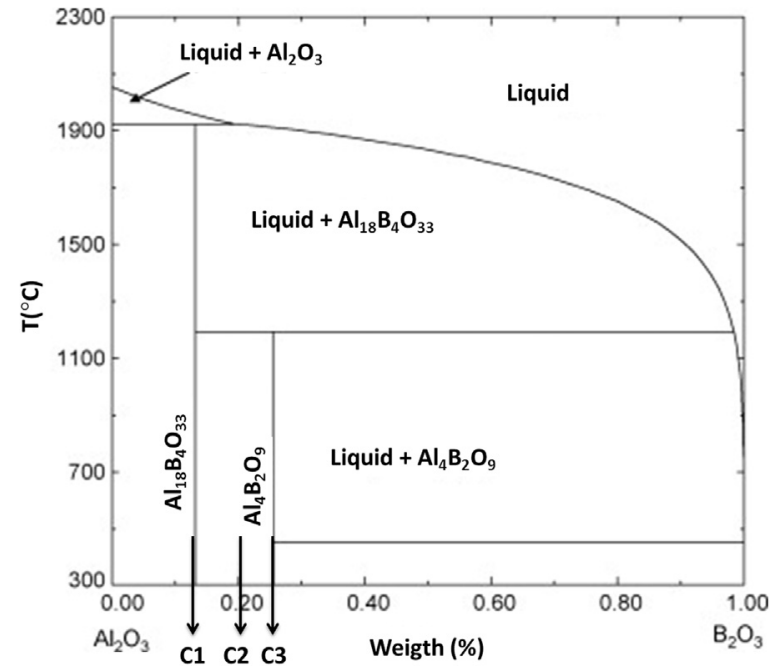

Fig. 1. $\mathrm{Al}_{2} \mathrm{O}_{3}-\mathrm{B}_{2} \mathrm{O}_{3}$ phase diagram. The arrows indicate the compositions tested, modified from [1].

synthesis route as well [18]. Besides alumina, metallic aluminum was proposed as the aluminum source $[19,20]$. Perhaps these complex processing routes might discourage the industrial application of these materials.

Much attention has been paid to the production of whiskers as nonmonolithic materials (powders and nanopowders) [3-5]. In this work, we intend to process monolithic porous ceramics for structural, insulating or filtering applications and to assess the technological properties of these materials.

Orthorhombic $\mathrm{Al}_{2} \mathrm{O}_{3}$-rich aluminoborate is an important ceramic material for which two slightly different compositions have been assumed: $\mathrm{Al}_{5} \mathrm{BO}_{9}\left(5 \mathrm{Al}_{2} \mathrm{O}_{3}: \mathrm{B}_{2} \mathrm{O}_{3}\right)$ and $\mathrm{Al}_{18} \mathrm{~B}_{4} \mathrm{O}_{33}\left(9 \mathrm{Al}_{2} \mathrm{O}_{3}: 2 \mathrm{~B}_{2} \mathrm{O}_{3}\right)$. The formula $\mathrm{Al}_{18} \mathrm{~B}_{4} \mathrm{O}_{33}\left(\mathrm{Al}_{4.91} \mathrm{~B}_{1.09} \mathrm{O}_{9}\right)$ was derived from the results of chemical analyses when crystal structure data were not yet available. Subsequent structural investigations indicated $\mathrm{Al}_{5} \mathrm{BO}_{9}$ composition. Nevertheless, $\mathrm{Al}_{18} \mathrm{~B}_{4} \mathrm{O}_{33}$ was still accepted as the correct stoichiometry assuming that additional $\mathrm{B}$ replaces $9 \% \mathrm{Al}$ [21]. This framework was employed in this work.

The objective of this work is to obtain materials from the $\mathrm{Al}_{2} \mathrm{O}_{3}$ $\mathrm{B}_{2} \mathrm{O}_{3}$ system, through a simple direct ceramic route, from inexpensive starting powders such as calcined alumina and boric acid. The aim is to study the critical processing variables, describe the properties achieved and the developed microstructure. This could be the starting point for developing porous aluminum borate materials with the aforementioned applications or for later molten aluminum (or aluminum alloy) infiltration for obtaining the ceramic-metallic composite. Furthermore the mechanical properties of the resultant complex microstructure borates material is no completely described in literature, in this work we also present the results of the diametral compression and elastic behavior of the materials obtained by the optimized route.

\section{Experimental procedure}

The starting raw materials employed were calcined alumina A2G (ALCOA, USA) and commercial boric acid (Borax Argentina SA, Argentina) with $99.8 \%$ of $\mathrm{H}_{3} \mathrm{BO}_{3},\left(56.2 \% \mathrm{~B}_{2} \mathrm{O}_{3}\right)$, CAS No.: 10043-35-3.

Boric acid was dry-milled in a disc and ring mill (Herzog HS-100). Alumina boric acid mixtures were performed in ethanol by stirring and sonication. Slurries were sieved in a \#325 sieve (ASTM). Dried $\left(110^{\circ} \mathrm{C}\right)$ mixtures were pressed in $1.0 \mathrm{~g}$ disc-shaped samples $(15.0 \mathrm{~mm}$ diameter) with a $100 \mathrm{MPa}$ uniaxial pressure.

Three compositions with 13.0, 20.5 and $26.0 \mathrm{wt} \%$ of boron oxide $\left(\mathrm{B}_{2} \mathrm{O}_{3}\right)$ were studied. They were labeled $\mathrm{C} 1, \mathrm{C} 2$ and $\mathrm{C} 3$, respectively.
The first and third correspond to the reported stoichiometric borates $\left(\mathrm{Al}_{18} \mathrm{~B}_{4} \mathrm{O}_{33}\right.$ and $\left.\mathrm{Al}_{4} \mathrm{~B}_{2} \mathrm{O}_{9}\right)$, as marked in Fig. 1 ; $\mathrm{C} 2$ is strictly an intermediate.

The thermal behavior of the mixtures was studied. Simultaneous thermogravimetric (TG) and differential thermal analyses (DTA) were performed up to $1200^{\circ} \mathrm{C}$. Both thermal analyses were carried out simultaneously at a $5{ }^{\circ} \mathrm{C} / \mathrm{min}$ heating rate in air atmosphere (TG-DTA and TMA Rigaku Evo plus II, Japan). The TG-DTA analysis of the boric acid was also performed to understand the chemical behavior of this starting powder.

After this analysis, samples were fired at the same heating rate $\left(5^{\circ} \mathrm{C} / \mathrm{min}\right)$ with different maximum temperatures in the range of $600-$ $1400^{\circ} \mathrm{C}$ and $120 \mathrm{~min}$ soaking in air atmosphere. In order to assess borate formation, the crystalline phases of sintered samples were determined by X-ray diffraction (XRD) using CuKa radiation operating at $40 \mathrm{kV}$ and $300 \mathrm{~mA}$ (Philips PW1710). The XRD patterns were analyzed with the program FullProf (version 4.90, July 2010), which is a multipurpose profile-fitting program [22], including Rietveld refinement to perform phase quantification $[23,24]$.

Once the sintering program was optimized, the linear shrinkage was measured; the green and sintered volumetric density was calculated from the volume: mass ratio. Archimedes immersion method was also carried out in the range $1100-1400{ }^{\circ} \mathrm{C}$.

The microstructure analysis was performed by a scanning electron microscope (SEM) (JEOL, JCM- 6000). Fracture strength is one of the most common and widely used mechanical properties for structural ceramics because it is the most simple and important material reliability parameter. The diametral compression test, also known as "splitting test" or "Brazilian test", has usually been employed in the mechanical evaluation due to several advantages: simpler piece preparation, simple geometry and quickness of testing, independent data with regard to surface finish and no edge effects [25-27]. In this case, the $15 \mathrm{~mm}$ diameter and $5 \mathrm{~mm}$ thick disc-shaped samples were diametrically compressed in a universal mechanical testing machine (INSTRON 5985, USA), at a constant strain rate of $0.1 \mathrm{~mm} / \mathrm{min}$, with steel plates. Lubricant paste was applied on the platen surfaces in contact with the disc to reduce the effect of friction; white and carbon papers were placed together between each platen and the disc for load distribution (padding material). The initial diameter was used for the calculation, and $\mathrm{L}$ was employed for the final maximum load of samples. For this method, the mechanical strength can be calculated with the following equation:

$\sigma_{d}=\frac{2 L}{\pi d t}$

where $L$ is the final load, $d$ is the diameter, and $t$ is the thickness of the disc-shaped sample.

\section{Results and discussion}

\subsection{Boric acid thermal behavior}

The thermal behavior of the boric acid can be seen in Fig. 2, where the thermogravimetric analysis (TG), the graphical derivative (dTG) and the differential thermal analysis (DTA) are presented. The water loss $(\approx 20 \mathrm{wt} \%)$ at low temperature (below $200^{\circ} \mathrm{C}$ ) can be observed in the TG curve; the dTG together with the DTA allow one to differentiate a three-step decomposition of the acid. These reactions correspond to Eqs. (2)-(4). The resulting oxide melts at $450{ }^{\circ} \mathrm{C}$ [1]. The observed mass losses correspond to the proposed stoichiometries, and the observed temperatures are in agreement with the literature results [28]. Apparently, the water sequential losses did not affect the compact integrity. No deterioration of the sample geometries was observed after these stages.

In the next section, the chemical processes of the alumina-boric acid mixtures are shown. As the alumina is inert at this temperature 


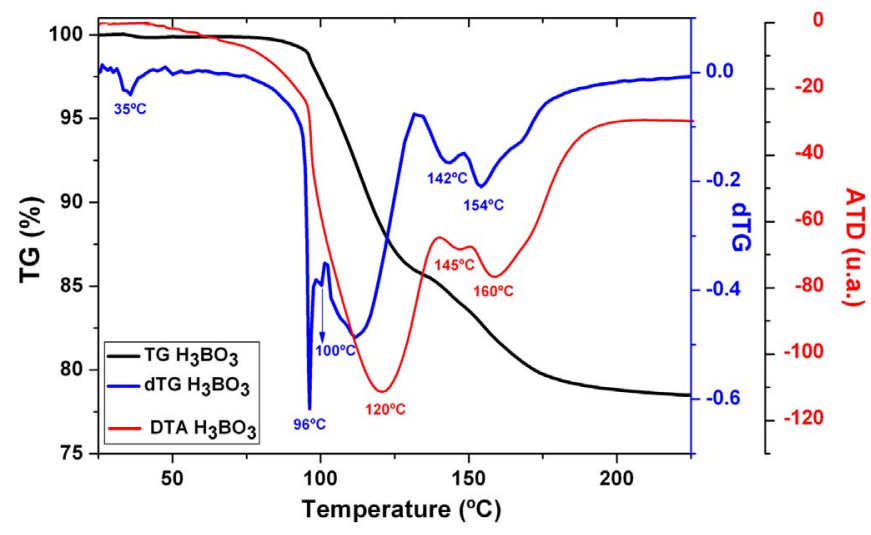

Fig. 2. Thermal behavior of the boric acid employed (TG, dTG and DTA).

range in the mixture treatments, the observed processes correspond to boric acid decomposition only.

$\mathrm{H}_{3} \mathrm{BO}_{3} \rightarrow \mathrm{HBO}_{2}+\mathrm{H}_{2} \mathrm{O}$

$4 \mathrm{HBO}_{2} \rightarrow \mathrm{H}_{2} \mathrm{~B}_{4} \mathrm{O}_{7}+\mathrm{H}_{2} \mathrm{O}$

$\mathrm{H}_{2} \mathrm{~B}_{4} \mathrm{O}_{7} \rightarrow 2 \mathrm{~B}_{2} \mathrm{O}_{3}+\mathrm{H}_{2} \mathrm{O}$

\subsection{Thermal behavior of the alumina-boric acid mixtures, and borate formation}

\subsubsection{Thermal analysis (TG, $d T G$ and DTA) of the boric acid-alumina} mixtures (C1-C2-C3)

The TG curve of the three proportions studied is shown in Fig. 3. As expected, the multistep mass loss can be observed in the three curves. The mass losses in the plot correspond to the water loss and are proportional to the amount of acid in the mixtures. No other important mass changes can be observed. It could be stated that the amount of boron oxide evaporation during the thermal treatment is null or negligible up to $1100{ }^{\circ} \mathrm{C}$.

The DTA analysis was performed simultaneously and is plotted in Fig. 4. As expected, the DTA curve follows the same trend as the endothermic peaks. The peak temperatures are included in the figure as well. Two broad and difficult to identify thermal signals associated with borate formations are observed in the three compositions at higher temperatures between 650 and $900{ }^{\circ} \mathrm{C}$. A second plot with a magnified scale is shown on the right-hand side of Fig. 4 in order to illustrate these signals.

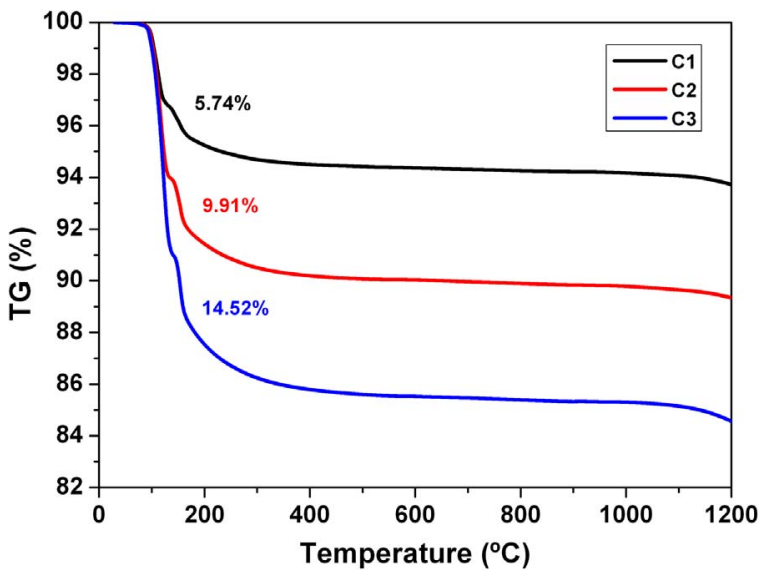

Fig. 3. TG of the alumina-boric acid mixtures ( $\mathrm{C} 1, \mathrm{C} 2$ and $\mathrm{C} 3$ compositions); mass losses correspond to boric acid decomposition.

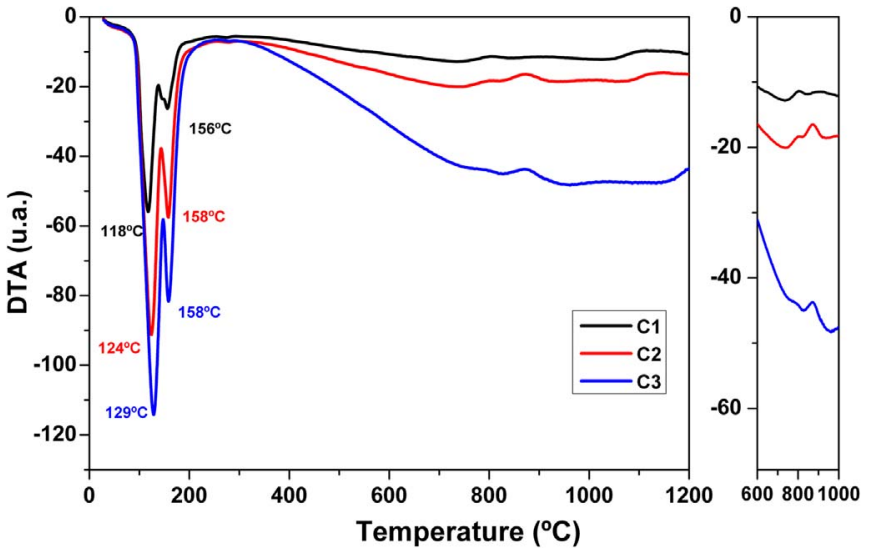

Fig. 4. Differential thermal analysis curves (DTA) of the $\mathrm{C} 1, \mathrm{C} 2$ and $\mathrm{C} 3$ compositions and magnified scale on the right-hand side.

\subsection{2. $X R D$ of the alumina-boric acid mixtures after thermal} treatments

In order to elucidate borate formation, an XRD analysis of the samples fired at consecutive maximum temperatures was performed only for C3 composition. Fig. 5 shows the XRD patterns of the samples fired in the $600-1400{ }^{\circ} \mathrm{C}$ range. In general, the identified peaks correspond to alumina (corundum; PDF 00-046-1212) and the two aluminum borates $\left(\mathrm{Al}_{18} \mathrm{~B}_{4} \mathrm{O}_{33}\right.$ : PDF 00-032-0003) and $\mathrm{Al}_{4} \mathrm{~B}_{2} \mathrm{O}_{9}$ (PDF 01-079-1477) $[29,30]$. Some boric acid (PDF 00-030-0199) was also detected after low temperature thermal treatments $\left(600\right.$ and $\left.700{ }^{\circ} \mathrm{C}\right)$; boric oxide $\left(\mathrm{B}_{2} \mathrm{O}_{3}\right.$ (PDF 01-076-1655)) was detected in the material fired at $800^{\circ} \mathrm{C}$.

Samples fired at 800 and $900{ }^{\circ} \mathrm{C}$ presented alumina and only one of the borates $\left(\mathrm{Al}_{4} \mathrm{~B}_{2} \mathrm{O}_{9}\right)$; after $1000{ }^{\circ} \mathrm{C}$ treatments the peaks of both borates $\left(\mathrm{Al}_{4} \mathrm{~B}_{2} \mathrm{O}_{9}\right.$ and $\left.\mathrm{Al}_{18} \mathrm{~B}_{4} \mathrm{O}_{33}\right)$ could be detected. Finally, materials fired at higher temperatures only showed the diffraction peaks of $\mathrm{Al}_{18} \mathrm{~B}_{4} \mathrm{O}_{33}$ together with some unreacted alumina.

The absence of the typical amorphous XRD band evidences the lack of an important amount of unreacted amorphous boron oxide in the resulting material [31,32]. Alumina peaks are observed. This can be explained by a local high alumina concentration that might be out of the equilibrium condition in the phase diagram, as expected, or by the small evaporation of boron oxide, and by the stoichiometric discrepancies for the aluminum borates described in recent work [21].

In order to illustrate the alumina disappearance and borate formations after the different thermal treatments, a qualitative analysis was performed. The main peak intensities (assumed as the peak height) of both phases are bar plotted as a function of the firing temperature in Fig. 6.

First, no borate formation could be observed after $600{ }^{\circ} \mathrm{C}$ treatments. Clearly, the formation is gradual and incomplete for mixtures fired between 700 and $1000{ }^{\circ} \mathrm{C}$, and almost complete for samples fired

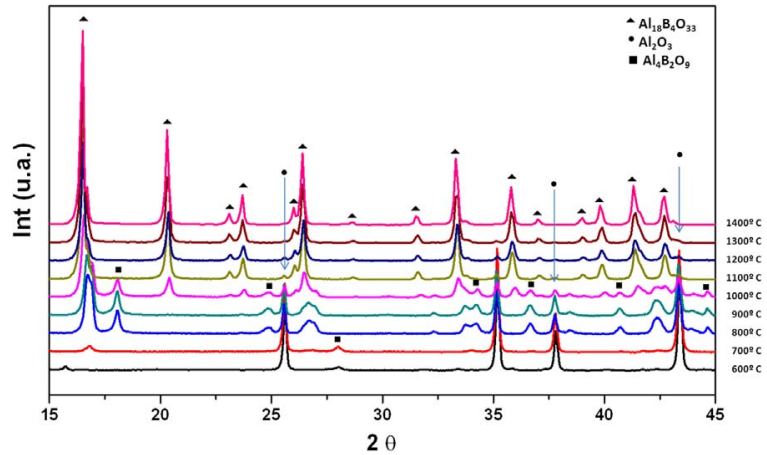

Fig. 5. XRD patterns of C 3 composition fired at different temperatures between 600 and $1400{ }^{\circ} \mathrm{C}$ (patterns were vertically translated for better visualization). 


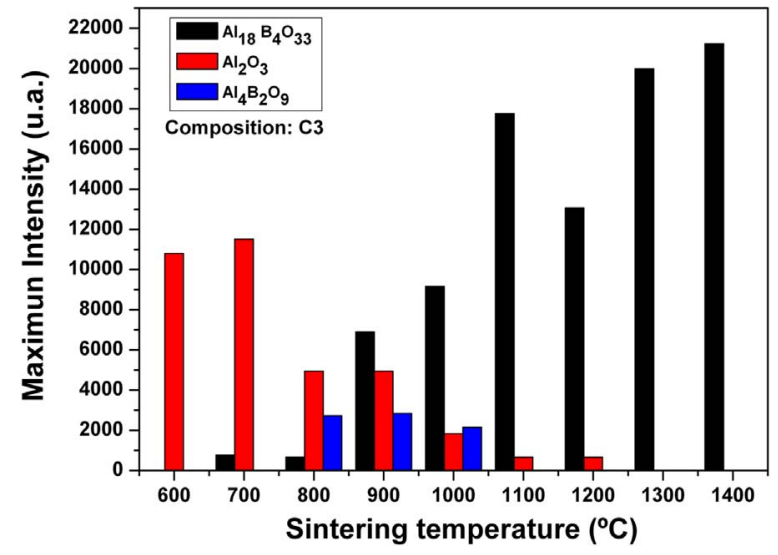

Fig. 6. Semiquantitative phase evolution with the firing temperature: main peak intensity as a function of the sintering temperature for the $\mathrm{C} 3$ mixture.

above this temperature. The proposed mechanism involves alumina dissolution in the boron oxide melt, and the consecutive crystallization of the borates $\left(\mathrm{Al}_{4} \mathrm{~B}_{2} \mathrm{O}_{9}\right.$ and $\left.\mathrm{Al}_{18} \mathrm{~B}_{4} \mathrm{O}_{33}\right)$ in whisker morphology. Seemingly, the first borate $\left(\mathrm{Al}_{4} \mathrm{~B}_{2} \mathrm{O}_{9}\right)$ is an intermediate in the thermal evolution of the $\mathrm{C} 3$ mixture. The kinetics of this reaction was partially described elsewhere [6]. Some catalysts such as other metal oxides were proposed as well, but they were not studied as they are out of the objectives of the present work. The formation of the intermediate would be related to the viscosity of the boron-based melt; at higher temperatures the lower viscosities would allow the dissolution and crystallization of borates during the thermal treatment, which was performed at $5{ }^{\circ} \mathrm{C} / \mathrm{min}$ and with a 60 -min dwelling time.

\subsection{Sintering, shrinkage and textural properties as a function of the processing temperature}

The low degree of sintering is consistent with that reported in the literature; high porosity materials are obtained due to the formation of aluminum borate needles [2,6,7,9-11].

In order to study the sintering behavior and the developed microstructure in this family of materials, three different approaches were carried out. First, the simple volumetric density was calculated from the mass: volume ratio. Then, the diametral shrinkage was compared. The dimensional stability of the probes permitted this measurement; the results are shown in Table 1. The third approach was the typical Archimedes analysis. The open porosity values are listed in Table 2.

The measured diametral shrinkage of the disc-shaped samples was around two percent in all the temperature range for $\mathrm{C} 2$ and $\mathrm{C} 3$; the almost independence of shrinkage from the firing temperature is an important advantage for the processing of this kind of material. The values observed for $\mathrm{C} 1$, with less boron, were even smaller but showed a small variation within the range of processing conditions.

The sintering parameter values (Tables 1 and 2) reveal that the thermal treatment of the alumina-boric acid mixtures cannot be defined as a strict sintering process. Hence, a porous microstructure

Table 1

Shrinkage and volumetric densities of the studied materials.

\begin{tabular}{|c|c|c|c|c|c|c|}
\hline \multirow[t]{2}{*}{$\begin{array}{l}\text { Firing } \\
\text { temperature }\left({ }^{\circ} \mathrm{C}\right)\end{array}$} & \multicolumn{3}{|c|}{ Relative shrinkage (\%) } & \multicolumn{3}{|c|}{$\begin{array}{l}\text { Volumetric density (g/ } \\
\left.\mathrm{cm}^{3}\right)\end{array}$} \\
\hline & C1 & C2 & C3 & C1 & C2 & C3 \\
\hline 1100 & 2.3 & 2.4 & 2.4 & 1.87 & 1.77 & 1.70 \\
\hline 1200 & 2.0 & 2.3 & 2.3 & 1.93 & 1.76 & 1.78 \\
\hline 1300 & 2.3 & 2.5 & 2.5 & 1.91 & 1.77 & 1.75 \\
\hline 1400 & 1.5 & 2.5 & 2.4 & 1.94 & 1.78 & 1.69 \\
\hline
\end{tabular}

Table 2

Archimedes open porosity of the studied materials.

\begin{tabular}{llll}
\hline \multirow{2}{*}{ Firing temperature $\left({ }^{\circ} \mathbf{C}\right)$} & \multicolumn{2}{l}{ Composition } & \\
\cline { 2 - 4 } & C1 (\%) & C2 (\%) & C3 (\%) \\
\hline $\mathbf{1 1 0 0}$ & 42.0 & 37.4 & 46.5 \\
$\mathbf{1 2 0 0}$ & 43.5 & 38.9 & 47.0 \\
$\mathbf{1 3 0 0}$ & 39.3 & 36.0 & 45.4 \\
$\mathbf{1 4 0 0}$ & 40.7 & 40.0 & 47.0 \\
\hline
\end{tabular}

will result, and the microstructure will be related to the small particle size of the starting powders (below $2.5 \mu \mathrm{m}$ in both cases). This porous microstructure will be a key characteristic for the potential applications of this family of materials.

The volumetric densities achieved (Table 2) were between 1.69 and $1.94 \mathrm{~g} / \mathrm{cm}^{3}$. The obtained values followed the sequence $\mathrm{C} 1>\mathrm{C} 2>\mathrm{C} 3$ in the studied range $\left(1100-1400{ }^{\circ} \mathrm{C}\right)$. The value for each composition was not affected by the maximum sintering temperature in the explored range. In fact, the deviation was below $0.05 \mathrm{~g} / \mathrm{cm}^{3}$.

The evaluated open porosities are listed in Table 2; the values are between $35 \%$ and $50 \%$ within the composition and temperature ranges studied. The shrinkage and volumetric density values were not significantly affected by the final thermal treatment temperature. Particularly, the open porosity presented the following sequence: C3 $>\mathrm{C} 1>\mathrm{C} 2$. Stoichiometric mixtures with a higher boron content exhibited the highest porosity, almost 50\%. A pore-forming agent could be incorporated in the processing route in order to achieve even higher porosities and better insulation performances.

\subsection{Crystalline phases of the materials developed from the $\mathrm{Al}_{2} \mathrm{O}_{3}$ - $\mathrm{B}_{2} \mathrm{O}_{3}$ system}

Equivalent XRD patterns were recorded for the three compositions explored $\left(\mathrm{C} 1, \mathrm{C} 2\right.$ and $\mathrm{C} 3$ ) in the $1100-1400{ }^{\circ} \mathrm{C}$ range. The Rietveld refinement was performed on the XRD patterns (not shown). The Rwp (weighted profile R-factor) parameters obtained in the 12 refinements were below 15.0 in all the cases, which indicates the goodness of the refinements. From this more accurate crystalline phase, quantification was obtained (Table 3). The refined structures correspond to the PDF codes in Section 3.2. Fisch et al. [21] found that the actual stoichiometries might differ from them. But in this analysis, those differences were neglected in order to assess the whole formation process.

C2 and C3 presented a similar behavior, while the behavior observed for $\mathrm{C} 1$ was different. For $\mathrm{C} 2$ and $\mathrm{C} 3$, a high $\mathrm{Al}_{18} \mathrm{~B}_{4} \mathrm{O}_{33}$ formation was achieved (over 90\%). The amount of unreacted $\mathrm{Al}_{2} \mathrm{O}_{3}$ and $\mathrm{Al}_{4} \mathrm{~B}_{2} \mathrm{O}_{9}$ intermediates was low and in general decreased with the maximum temperature. Moreover, C3 conversion was slightly higher than that of $\mathrm{C} 2$.

However, in $\mathrm{C} 1$ an important amount (around 60\%) of unreacted alumina was quantified. The formation of $\mathrm{Al}_{18} \mathrm{~B}_{4} \mathrm{O}_{33}$ was only approximately $40 \%$. Only traces of $\mathrm{Al}_{4} \mathrm{~B}_{2} \mathrm{O}_{9}$ were detected for the $\mathrm{C} 1$ materials fired at 1100 and $1200{ }^{\circ} \mathrm{C}$. As thoroughly described by Fisch et al., since the actual stoichiometries of these aluminum borates remain undetermined, some discrepancies between the initial boron-alumina proportion and the evaluated proportions (assuming perfect stoichiometry) could be found. The objective of the performed analysis was only to illustrate the progress of aluminum borate formation.

\subsection{Microstructural analysis, scanning electron microscopy (SEM), and effect of the sintering temperature}

SEM images of the developed materials are depicted in Figs. 7 and 8. In Fig. 7, SEM images of the $\mathrm{C} 3$ material fired at different temperatures $\left(1100-1400{ }^{\circ} \mathrm{C}\right)$ are shown. The nondensified microstructure evaluated by the Archimedes method is observed. From these 
Table 3

Crystalline phase quantification of the developed materials, effect of the initial composition and firing temperature.

\begin{tabular}{|c|c|c|c|c|c|c|c|c|c|}
\hline \multirow[t]{2}{*}{ Sintering temp. $\left({ }^{\circ} \mathrm{C}\right)$} & \multicolumn{3}{|l|}{$\mathrm{C} 1$} & \multicolumn{3}{|l|}{$\mathrm{C} 2$} & \multicolumn{3}{|l|}{$\mathrm{C} 3$} \\
\hline & $\mathrm{Al}_{2} \mathrm{O}_{3}$ & $\mathrm{Al}_{18} \mathrm{~B}_{4} \mathrm{O}_{33}$ & $\mathrm{Al}_{4} \mathrm{~B}_{2} \mathrm{O}_{9}$ & $\mathrm{Al}_{2} \mathrm{O}_{3}$ & $\mathrm{Al}_{18} \mathrm{~B}_{4} \mathrm{O}_{33}$ & $\mathrm{Al}_{4} \mathrm{~B}_{2} \mathrm{O}_{9}$ & $\mathrm{Al}_{2} \mathrm{O}_{3}$ & $\mathrm{Al}_{18} \mathrm{~B}_{4} \mathrm{O}_{33}$ & $\mathrm{Al}_{4} \mathrm{~B}_{2} \mathrm{O}_{9}$ \\
\hline 1100 & 61.7 & 38.0 & 0.3 & 11.8 & 86.4 & 1.8 & 3.6 & 94.9 & 1.5 \\
\hline 1200 & 55.8 & 43.15 & 1.1 & 7.8 & 91.2 & 1.0 & 5.0 & 93.3 & 1.7 \\
\hline 1300 & 58.0 & 42.0 & 0 & 0.4 & 99.2 & 0.4 & 0.7 & 97.4 & 1.9 \\
\hline 1400 & 66.9 & 33.1 & 0 & 6.3 & 93.6 & 0.1 & 0.3 & 99.5 & 0.2 \\
\hline
\end{tabular}

images, the microstructure can be characterized. An evident whisker or nanorod morphology could be defined in all the materials developed; the aspect ratio was at least 20:1. The measured open porosity corresponds to the space between needles. The whisker thickness was relatively homogeneous for each material. This morphology was previously reported $[2,6,7,9-11]$ for aluminum borates and is consistent with the borate formation observed after the XRD analysis. However, the two borates observed were not differentiated by the microstructural analysis; the unreacted alumina particles were also difficult to observe.

The needles showed no preferential direction. Regarding the morphology of the nanorods, the whiskers presented angled and rectangular sections after $1100{ }^{\circ} \mathrm{C}$ treatments. They have a tendency to overlap. After higher temperature treatments, this morphology was gradually smoothed forming larger needles with rounded section. The aspect ratio qualitatively decreased with increasing sintering temperature. However, the thickness observed was in all the cases submicronic. The sintering process was always local; the observed sample shrinkage was only around $2 \%$.

The fracture surface was evaluated using the indirect diametral compression test (described in Section 3.7). No cracks were observed in the whisker, showing the high mechanical properties of the individual grains. The interlocked needle microstructure configuration leads to good mechanical behavior, and this coupled with high porosity (50\%) encourage the thermal insulating application. Porous ceramic might have potential filtering applications as well. Finally, the microstructures have a high specific area and might be employed for heterogeneous catalysis and adsorption uses.

\subsection{Microstructural analysis, scanning electron microscopy and effect of the composition}

The porosity was in the $35-50 \%$ range and was affected by the starting composition, following the sequence $\mathrm{C} 3>\mathrm{C} 1>\mathrm{C} 2$. Fig. 8 shows the SEM images of materials $\mathrm{C} 1, \mathrm{C} 2$ and $\mathrm{C} 3$ fired at $1200{ }^{\circ} \mathrm{C}$ at two different magnifications. The whisker or nanorod morphology can be identified in the three materials. In this case, the effect of the alumina: boron ratio is evident; some unreacted alumina particles are imbibed in the whisker matrix of the $\mathrm{C} 1$ materials. They were not observed for the C3 material with the highest boron content. The whisker thickness after this particular thermal treatment was also affected by the starting composition. Materials with less available boron presented thinner needles.

\subsection{Mechanical properties and diametral compression behavior}

In order to assess the possible application of these porous materials, a simple mechanical characterization was carried out. This behavior will undoubtedly be affected by the developed microstructure, with high porosity (around 50\%) and partially sintered interlocked (submicronic in diameter) needles, homogeneous in size and morphology, with no preferential orientation. The mechanical characterization was carried out for the materials fired at $1200{ }^{\circ} \mathrm{C}$.

The three compositions studied (C1, C2 and C3) were evaluated. Six samples were submitted to the compression tests.
The diametral compression strength $\left(\sigma_{\mathrm{d}}\right)$ was calculated from the maximum stress (Eq. (1)), and a diametral elastic modulus $\left(\mathrm{E}_{\mathrm{d}}\right)$ was calculated from the slope of the final linear section of the stress-strain curves.

The mean diametral strengths $\left(\sigma_{\mathrm{d}}\right)$ and deviation are listed in Table 4. The slope of the linear range was calculated from a linear fitting; fit goodness $\left(\mathrm{R}^{2}\right)$ was over 99.5 in all the cases. The mean slopes $\left(E_{d}\right)$ together with the corresponding deviations are also shown in Table 4. $\mathrm{E}_{\mathrm{d}}$ is related to the Young's elastic modulus of the material and, like every mechanical property, would be strongly affected by the microstructure and particularly by the (decreased) porosity of the material, which, as described, is important in these porous materials $[33,34]$. As expected for this complex microstructure in absolute values the obtained $E_{d}$ are below the reported stiffness of the borate crystals. However this fact might be explained by the developed low relative density of the present aluminum borate based materials.

Evidently, the strength achieved encourages the use of these materials for structural applications, especially due to their relatively low density and high porosity.

In all the cases, the relative experimental deviation was below $15 \%$ for the strength, which sustains the experimental strength evaluated. The calculated deviation for the slope was over this value, especially for the $\mathrm{C} 1$ material.

The C2 composition fired at $1200{ }^{\circ} \mathrm{C}$, fully converted with lower porosity, presented the highest strength. The $\mathrm{C} 3$ composition, with the highest boron content and the highest porosity (almost 50\%), presented a relatively high $12.6 \mathrm{MPa}$ value, evidencing the technological merits of this material. The strength observed for the $\mathrm{C} 1$ material was lower and could restrain its use.

\section{Conclusions}

A series of porous aluminum borate $\left(\mathrm{Al}_{18} \mathrm{~B}_{4} \mathrm{O}_{33}\right)$ materials were obtained from a simple direct mixture of alumina and boric acid by an inexpensive processing route. The materials presented high porosity (reaching 50\%) and partially sintered interlocked (submicronic in diameter) needles, homogeneous in size and morphology (over 20:1), with no preferential orientation. Borate formation was confirmed and studied by thermal analysis and XRD; the formation started at around $1000{ }^{\circ} \mathrm{C}$ and was completed for materials fired above $1200{ }^{\circ} \mathrm{C} . \mathrm{Al}_{4} \mathrm{~B}_{2} \mathrm{O}_{9}$ was found to be an intermediate. Some of the microstructural properties such as needle section shape and thickness were affected by both processing variables studied.

The mechanical behavior of the complex needle porous microstructure was evaluated. The evaluated material indirect stiffness $(\approx 800 \mathrm{MPa}$ ) was much lower than the reported aluminum borate grain value $(400 \mathrm{GPa}$ ) this reveals the microstructure effect in the mechanical behavior, this is related to the low relative density developed in the present borate based materials. The mechanical characterization revealed a not completely fragile behavior of the developed materials. The slope of the stress-strain curves, in diametral configuration, presented low values; again this is explained by the low relative density, the needle microstructure and pore size and distribution. The diametral compression resistance was over $10 \mathrm{MPa}$, which together with the other characteristics described encourage the applica- 

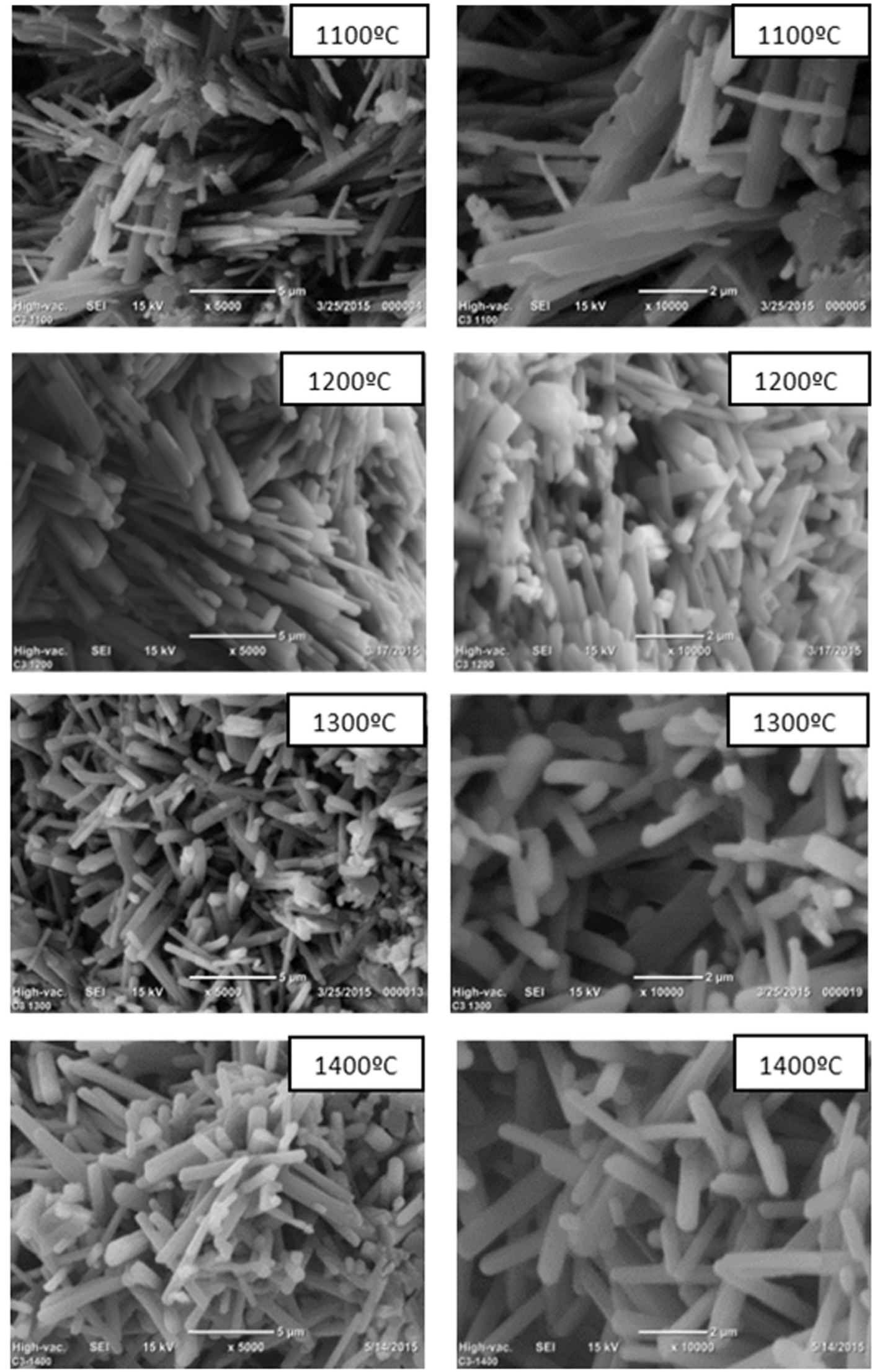

Fig. 7. SEM images of whiskers of composition C3 at different temperatures (left, $\times 5000$; right, $\times 10,000$ ). 

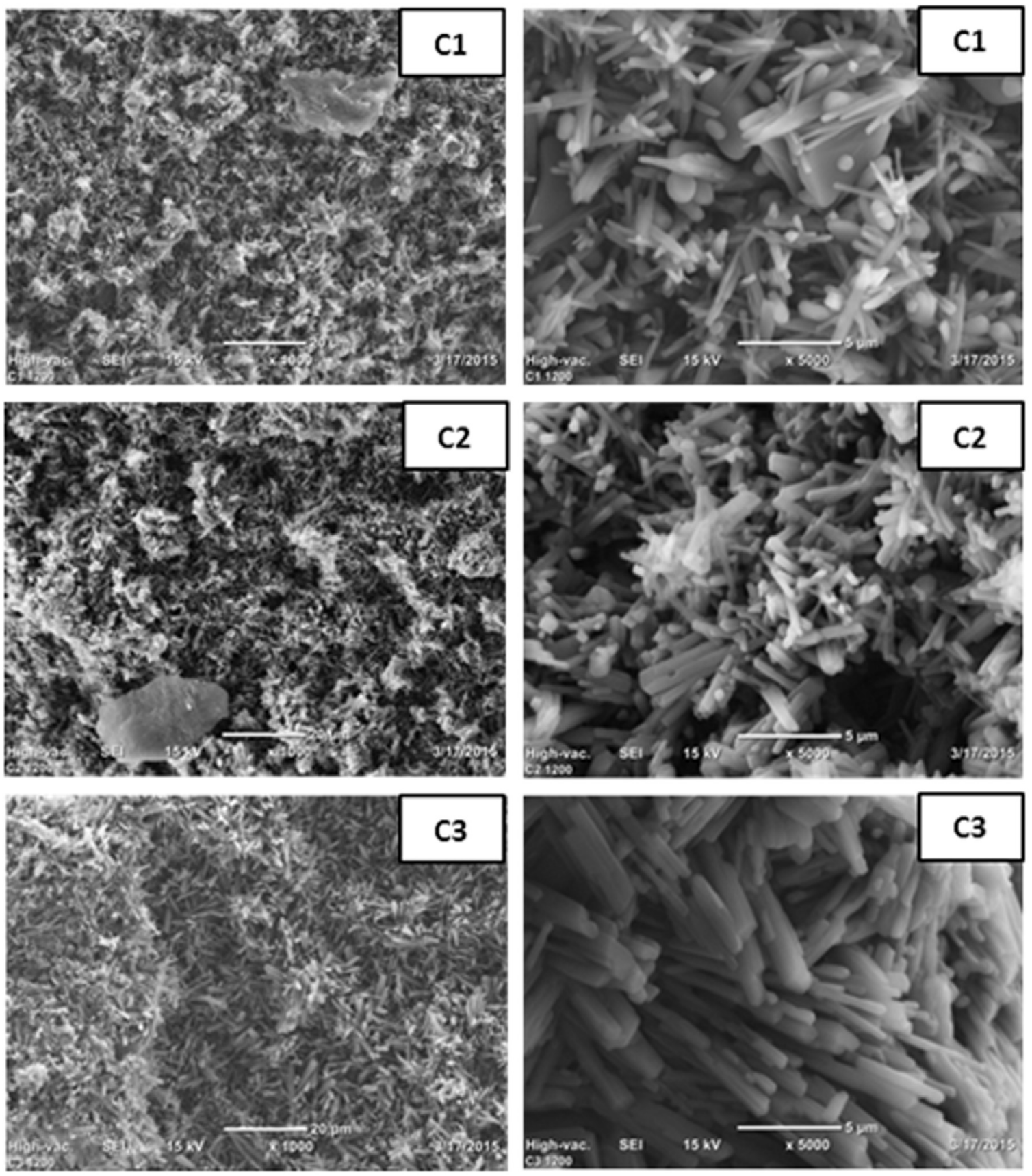

Fig. 8. SEM images of whiskers of compositions $\mathrm{C} 1, \mathrm{C} 2$ and $\mathrm{C} 3$ at $1200{ }^{\circ} \mathrm{C}(\mathrm{left}, \times 1000$; right, $\times 5000)$.

Table 4

Mechanical properties of the materials sintered at $1200{ }^{\circ} \mathrm{C}$.

\begin{tabular}{lllll}
\hline Composition & $\begin{array}{l}\boldsymbol{\sigma}_{\mathbf{d}} \\
\text { (MPa) }\end{array}$ & err & $\begin{array}{l}\mathbf{E}_{\mathbf{d}} \\
\text { (MPa) }\end{array}$ & err \\
\hline C1 & 4.7 & 0.6 & 270 & 125 \\
C2 & 16.2 & 1.2 & 840 & 150 \\
C3 & 12.6 & 1.3 & 860 & 260 \\
\hline
\end{tabular}

tion of the developed materials.

Thus, based on the information gathered from our research, aluminum borate ceramic materials can be designed for structural, insulating or filtering applications employing only alumina and boric acid as boron oxide source.

These materials could be infiltrated by molten aluminum or aluminum alloys as well.

\section{Acknowledgments}

This work has been partially supported by Nano-Petro FONARSEC Project 2012 (ANPCyT). MFH acknowledges CONICET and Y-Tec for the fellowship.

\section{References}

[1] P.J.M. Gielisse, W.R. Foster, The System $\mathrm{Al}_{2} \mathrm{O}_{3}-\mathrm{B}_{2} \mathrm{O}_{3}$, Nature 195 (1962) 69-70. [2] S.P. Ray, Preparation and characterization of aluminum borate, J. Am. Ceram. Soc 75 (1992) 2605-2609.

[3] K.P. Peil, L.G. Galya, G. Marcelin, Acid and catalytic properties of nonstoichiometric aluminum borates, J. Catal. 115 (1989) 441-451.

[4] W.J. Wang, Y.W. Chen, Alumina-aluminum borates as solid acid catalysts, Catal. Lett. 10 (1991) 297-304.

[5] S.A. El-Hakam, E.A. El-Sharkawy, Structural characterization and catalytic properties of aluminum borates-alumina catalysts, Mater. Lett. 36 (1998) 167-173.

[6] K. Suganuma, T. Fujita, G. Sasaki, N. Suzuki, Evaluation of strength and heat- 
resistance for aluminum-borate whisker reinforced AC8A aluminum alloy composite, J. Japan Inst. Light Metals 41 (1991) 270-275. http://dx.doi.org/10.2464/ jilm.41.270.

[7] M. Yoshida, S. Takeuchi, J. Pan, G. Sasaki, N. Fuyama, T. Fuj, H. Fukunaga, Preparation and characterization of aluminum borate whisker reinforced magnesium alloy composites by semi-solid process, Adv. Compos. Mater. 8 (1999) $259-268$.

[8] H.K. Lee, S. Zerbetto, P. Colombo, C.G. Pantano, Glass-ceramics and composites containing aluminum borate whiskers, Ceram. Int. 36 (2010) 1589-1596.

[9] Chun Cheng, X.X. Ding, F.J. Shi, Yun Cheng, X.T. Huang, S.R. Qi, C. Tang, Preparation of aluminum borate nanowires, J. Cryst. Growth 263 (2004) 600-604.

[10] L.M. Peng, X.K. Li, H. Li, J.H. Wang, M. Gong, Synthesis and microstructural characterization of aluminum borate whiskers, Ceram. Int. 32 (2006) 365-368.

[11] Y. Li, R.P.H. Chang, Synthesis and characterization of aluminum borate $\left(\mathrm{Al}_{18} \mathrm{~B}_{4} \mathrm{O}_{33}\right.$, $\mathrm{Al}_{4} \mathrm{~B}_{2} \mathrm{O}_{9}$ ) nanowires and nanotubes, Mater. Chem. Phys. 97 (2006) 23-30.

[12] E.M. Elssfah, H.S. Song, C.C. Tang, J. Zhang, X.X. Ding, S.R. Qi, Synthesis of aluminum borate nanowires via a novel flux method, Mater. Chem. Phys. 101 (2007) 499-504.

[13] S. Peng, H. Jinwen, W. Wenwei, Preparation of aluminum borate whiskers by the molten salt synthesis method, Ceram. Int. 39 (2013) 7263-7267.

[14] R.K. Gupta, A.A. Al-Ghamdi, O.A. Al-Hartomy, F. Al-Hazmi, F. El-Tantawy, F. Yakuphanoglu, Synthesis and characterization of nanostructured aluminum borate by sol-gel method, J. Sol-Gel Sci. Technol. 64 (2012) 100-103.

[15] J. Zhou, D. Su, J. Luo, M. Zhong, Synthesis of aluminum borate nanorods by a lowheating-temperature solid-state precursor method, Mater. Res. Bull. 44 (2009) 224-226.

[16] I.E. Gonenli, A.C. Tas, Chemical preparation of aluminum borate whiskers, Powder Diffr. 15 (2000) 104-107.

[17] J. Wang, G. Ning, X. Yang, Z. Gan, H. Liu, Y. Lin, Large-scale synthesis of $\mathrm{Al}_{4} \mathrm{~B}_{2} \mathrm{O}_{9} /$ $\mathrm{Al}_{18} \mathrm{~B}_{4} \mathrm{O}_{33}$ whiskers via a novel method, Mater. Lett. 62 (2008) 1208-1211.

[18] J. Wang, G. Ning, Y. Lin, Chemical synthesis of $\mathrm{Al}_{18} \mathrm{~B}_{4} \mathrm{O}_{33}$ whiskers via a combustion method, Mater. Lett. 62 (2008) 2447-2449.

[19] Y. Liu, Q. Li, S. Fan, Self-catalytic growth of aluminum borate nanowires, Chem. Phys. Lett. 375 (2003) 632-635.

[20] Z. Yu, N. Zhao, E. Liu, C. Shi, X. Du, J. Wang, Low-temperature synthesis of aluminum borate nanowhiskers on the surface of aluminum powder promoted by ball-milling pretreatment, Powder Technol. 212 (2011) 310-315.
[21] M. Fisch, T. Armbruster, D. Rentsch, E. Libowitzky, T. Pettke, Crystal-chemistry of mullite-type aluminoborates $\mathrm{Al}_{18} \mathrm{~B}_{4} \mathrm{O}_{33}$ and $\mathrm{Al}_{5} \mathrm{BO}_{9}$ : a stoichiometry puzzle, J. Solid State Chem. 184 (2011) 70-80.

[22] J. Rodríguez-Carvajal, Recent developments of the program FULLPROF, in Commission on commission on powder diffraction (IUCr), Newsletter 26 (2001) 12-19.

[23] D.L. Bish, J.E. Post, Quantitative mineralogical analysis using the Rietveld fullpattern fitting method, Am. Mineral. 78 (1993) 932-940.

[24] M.R. Gauna, M.S. Conconi, S. Gomez, G. Suárez, E.F. Aglietti, N.M. Rendtorff, Monoclinic-tetragonal zirconia quantification of commercial nanopowder mixtures by XRD and DTA, Ceram. Silik. 50 (2015) 318-325.

[25] M.K. Fahad, Stresses and failure in the diametral compression test, J. Mater. Sci. 31 (1996) 3723-3729.

[26] C. Rocco, G.V. Guinea, J. Planas, M. Elices, Review of the splitting-test standards from a fracture mechanics point of view, Cem. Concr. Res. 31 (2001) 73-82.

[27] M.F. Serra, M.F. Acebedo, M.S. Conconi, G. Suarez, E.F. Aglietti, N.M. Rendtorff, Thermal evolution of the mechanical properties of calcareous earthenware, Ceram. Int. 40 (2014) 1709-1716.

[28] M.F. Gazulla, M.P. Gómez, M. Orduña, G. Silva, Caracterización química, mineralógica y térmica de boratos naturales y sintéticos, Bol. Soc. Esp. Ceram. V 44 (2005) 21-31.

[29] H. Lührs, R.X. Fischer, H. Schneider, Boron mullite: formation and basic characterization, Mater. Res. Bull. 47 (2012) 4031-4042.

[30] D. Mazza, M. Vallino, G. Busca, Mullite-type structures in the systems $\mathrm{Al}_{2} \mathrm{O}_{3}-\mathrm{Me}_{2} \mathrm{O}$ $(\mathrm{Me}=\mathrm{Na}, \mathrm{K})$ and $\mathrm{Al}_{2} \mathrm{O}_{3}-\mathrm{B}_{2} \mathrm{O}_{3}$, J. Am. Ceram. Soc. 75 (7) (1992) 1929-1934.

[31] A. Atasoy, The aluminothermic reduction of boric acid, Int. J. Refract. Met. Hard Mater. 28 (2010) 616-622.

[32] H.B. Pan, X.L. Zhao, X. Zhang, K.B. Zhang, L.C. Li, Z.Y. Li, W.M. Lam, W.W. Lu, D.P. Wang, W.H. Huang, K.L. Lin, J. Chang, Strontium borate glass: potential biomaterial for bone regeneration, J. R. Soc. Interface (2009). http://dx.doi.org/ 10.1098/rsif.2009.0504.

[33] R.W. Rice, Porosity of Ceramics: Properties and Applications, CRC Press, irconia, 1998

[34] S. Gómez, G. Suárez, N.M. Rendtorff, E.F. Aglietti, Relation between mechanical and textural properties of dense materials of tetragonal and cubic zirconia, Sci. Sinter. 48 (2016) 119-130. 